An Age in Motion 


\section{Asia East by South}

A series published under the auspices of the Southeast Asia Program, Cornell University

An Age in Motion: Popular Radicalism in Java, I9I 2-I926, by Takashi Shiraishi 


\section{An Age in Motion}

Popular Radicalism in Java, I9I2-I926

\section{TAKASHI SHIRAISH I}

Cornell University Press

ITHACA AND LONDON 
THIS BOOK HAS BEEN PUBLISHED WITH THE AID OF A GRANT FROM THE HULL MEMORIAL PUBLICATION FUND OF CORNELL UNIVERSITY.

\section{Copyright (C) I 990 by Cornell University}

All rights reserved. Except for brief quotations in a review, this book, or parts thereof, must not be reproduced in any form without permission in writing from the publisher. For information, address Cornell University Press, I 24 Roberts Place, Ithaca, New York 14850.

First published r 990 by Cornell University Press.

International Standard Book Number 0-80 I 4-2 I 88-8

Library of Congress Catalog Card Number 89-37476

Printed in the United States of America

Librarians: Library of Congress cataloging information appears on the last page of the book.

(2) The paper used in this publication meets the minimum requirements of the American National Standard for Permanence of Paper for Printed Library Materials Z39.48-r984. 
To Saya 
Digitized by the Internet Archive in 2018 with funding from

The Arcadia Fund 